\title{
SITUS OF SHARES ISSUED UNDER THE UNIFORM STOCK TRANSFER ACT.
}

\section{Charles P. Hine $\dagger$}

It must be conceded that decisions as to the situs of shares not subject to the Uniform Stock Transfer Act have attributed to them a sort of fourth-dimensional quality-an ability to be physically present in two different states at the same time-so that actions quasi in rem may be brought in either state on the theory that the state where the action is brought has such complete control over the res that it may determine the rights of non-resident claimants served by publication.

Numerous decisions of the highest authority dealing with such shares have held that actions quasi in rem may be brought in the state of incorporation ${ }^{1}$ while other decisions of the same courts have permitted seizure of the res ${ }^{2}$ or actions quasi in rem $^{3}$ in the jurisdiction where the certificates were located.

This state of the law was unsatisfactory and likely to lead to conflicting decisions in different jurisdictions as to title to the same shares. The rule that the court which first seizes the res in an action quasi in rem has exclusive jurisdiction ${ }^{4}$ does not afford a complete solution to this problem, since the several courts might differ on questions of fact and law as to what constitutes an effective seizure of such an intangible as a share of stock. ${ }^{5}$

The Uniform Stock Transfer Act-by its provisions that "title to a certificate and to the shares represented thereby" shall be transferred only by delivery of the certificate, ${ }^{6}$ that notwithstanding the transfer of a certificate and the shares represented thereby has been rescinded or set aside, nevertheless, a subsequent bona fide purchaser of the certificate from the transferee in possession of the certificate acquires "an inde-

$\dagger$ A. B., I898, LL. B., I90I, Yale University; member of the Cleveland Bar; author of articles in various legal periodicals.

I. Jellenik v. Huron Copper Mining Co., I77 U. S. I (Ig0o); Thompson v. Terminal Shares, Inc., 89 F. (2d) 652 (C. C. A. 8th, I937); Sohege v. Singer Mfg. Co., 73 N. J. Eq. 567, 68 Ati. 64 (Ch. 1907).

2. Direction der Disconto-Gesellschaft v. United States Steel Corp., 267 U. S. 22 (1925) ; Pilger v. United States Steel Corp., ro2 N. J. Eq. 506, 141 At1. 737 (Ch. rg28).

3. Merritt v. American Steel-Barge Co., 79 Fed. 228 (C. C. A. 8th, I897) ; Franz v. Buder, II F. (2d) 854 (C. C. A. 8th, 1926); Norrie v. Lohman, I6 F. (2d) 355 (C. C. A. 7 th, 1926).

4. Iion Bonding Co. v. Karatz, 262 U. S. 77 (1923); Harkin v. Brundage, 276 U. S. 36 (1928).

5. See Harvey v. Fiduciary Trust Co., I3 N. E. (2d) 299, 305-6 (Mass. 1938); Hanna v. Stedman, 230 N. Y. 326, 336, I30 N. E. 566, 569 (I92I).

6. UnIform Stock Transfer ACT, \& I, 6 U. L. A. \& I (Ig22). 
feasible right to the certificate and the shares represented thereby", ${ }^{7}$ and that "no attachment or levy upon shares of stock for which a certificate is outstanding shall be valid until such certificate be actually seized by the officer making the attachment or levy, or be surrendered to the corporation which issued it, or its transfer by the holder be enjoined"- ${ }^{8}$ seemed to declare in unmistakable terms that the share was embodied in the certificate and that jurisdiction over the shareholder's separate property interest, evidenced by a lawfully issued certificate, depended on the location of such certificate.

However, a number of decisions have held that suits quasi in rem, affecting the title of non-resident certificate holders to shares subject to the Uniform Stock Transfer Act, may still be brought in the state of incorporation on the theory that the share continues to be personal property in that state for purposes other than attachment or garnishment, in actions at law. ${ }^{9}$ Some of these decisions have held that the share is effectively seized by making the corporation a party to the suit, and a few have actually held that the corporation is not an indispensable party. ${ }^{10}$

This uncertain state of the common law on the subject is doubtless the reason why the authors of the Restatement of Conflict of Laws, in their final draft of Section 53 (3), ${ }^{11}$ modified the corresponding section of the tentative draft of Section 57 (3) which provided:

"(3) To the extent to which the state in which the corporation was organized merges the share in the certificate, the share is exclusively subject to the jurisdiction of the state which has jurisdiction over the certificate." 12

7. Id. $\S 8$.

8. $I d$. \& $\mathrm{x}$.

9. Harvey v. Harvey, 29o Fed. 653 (C. C. A. 7 th, 1923); McQuillen v. National Cash Register Co., 13 F. Supp. 53 (D. Md. 1935); Shinkle v. Dalton Adding Machine Co., r9 Ohio N. P. (N. S.) 104 (C. P. I9I6); see Warren v, New Jersey Zinc Co., II6 N. J. Eq. 315, 326, I73 Atl. 128, I33 (Ch. 1934), distinguished, Elgart v. Mintz, I23 N. J. Eq. 404, 413, 197 Atl. 747, 752 (Ch. 1938).

Io. Harvey v. Harvey, 290 Fed. 653 (C. C. A. 7th, r923). Cf. Kendig v. Dean, 97 U. S. $423(1878)$, in which the Court held that the corporation was an indispensable party to any relief which a court of equity could give in that case. While the bill did not in terms pray for a decree quieting the plaintiff's title as against defendant, it is clear that the bill made out a case which under the prayer for general relief would have entitled plaintiff to a decree quieting plaintiff's title as against defendant's claim if such suit could have been entertained by a court of equity without making the corporation a party.

II. Restatement, Conflict of Laws (I934) $\$ 53$ (3): "To the extent to which the law of the state in which the corporation was incorporated embodies the share in the certificate, the share is subject to the jurisdiction of the state which has jurisdiction over the certificate."

12. This section of the tentative draft is cited with approval in Hutchison v. Ross, 262 N. Y. $381,390,187$ N. E. 65,69 (r933). The subject of situs of shares is treated in the following articles in legal periodicals: Pomerance, The Situs of Stock (I93I) I7 CoRn. L. Q. 43 ; Notes (I937) 85 U. of PA. L. Rev. 522, (1927) I5 Cal IF. L. Rev. 145, (1925) g MrNN. L. Rev. 66I, (1933) I9 VA. L. REv. 386, (I935) 10 WIs. L. REv. 513; (I936) 45 YALE L. J. 379. For purposes of administration of a decedent's estate the 
The purpose of this article is to point out that fundamental principles applicable to the determination of situs require a decision that the only situs of valid shares, represented by a lawfully issued certificate subject to the Uniform Stock Transfer Act, is in the state where the certificate is located, and that decisions to the contrary have resulted from the tendency of overworked judges to follow precedents without adequate consideration of the reasons on which such precedents were based.

The leading case on the subject of the situs of shares in actions quasi in rem, decided prior to the adoption of the Uniform Stock Transfer Act by any state, was Jellenik v. Huron Copper Mining Co. ${ }^{13}$ Since this case is relied on in all of the subsequent cases dealing with stock issued under the Uniform Act, it is worth while to consider some of the important facts of that case, as well as its ratio decidendi.

In that case the plaintiffs had been stockholders of record and, according to the allegations of the petition, were still stockholders although the defendant officials had wrongfully and fraudulently caused their shares to be sold. The decision that the court of the state of incorporation had jurisdiction quasi in rem rested primarily on three propositions: (I) that under the statutes of Michigan then in force, shares of a Michigan corporation were personal property in that state which could be attached or levied on by serving the writ of attachment or execution on the corporation; ${ }^{14}$ (2) that the Michigan corporation, by virtue of the Michigan statutes, could be required by final decree "to cancel on its books such certificates held by persons outside of the state and regard the plaintiffs as the real owners of the property interest represented by them;" ${ }^{15}$ (3) that "the certificates are only evidence of the ownership of the shares and the interest represented by the shares is held by the Company for the benefit of the true owner. As the habitation or domicile of the Company is and must be in the State that created it, the property represented by its certificates of stock may be deemed to be held by the company within the state whose creator it is, whenever it is sought by suit to determine who is its real owner." 16

Taking up in order the three propositions upon which the Jellenik decision was based, it is obvious that the first reason does not exist under the Uniform Stock Transfer Act. The fact that states which have adopted the Uniform Act deny, even to one who has obtained judgment

situs of shares represented by a lawfully issued certificate is in the state where the certificate is located. Restatement, Conflict of Laws (I934) $\$ \$ 486$ ( $\mathrm{I}$ ) and 477 , comment $c$.

I3. I77 U. S. I (1900).

I4. Id. at $\mathrm{I} 2, \mathrm{I} 3$.

I5. Id. at I3, I4.

I6. Id. at I3. 
in the courts of the state of incorporation, the right to reach the judgment debtor's interest as a shareholder in a corporation, unless the certificate can be levied on, is persuasive evidence that the legislatures of such states did not intend that shares thereafter issued should be considered personal property in the state for purposes of litigation between individuals, involving title to lawfully issued shares, unless the certificates were in the state. There is no basis in reason for holding that one who has not established his rights at law or in equity-who alleges, for instance, that he was induced by fraud to cause the issue of the certificate in the name of another who holds it outside the state - should be given the right to treat his mere equitable claim to the shares as property within the state for the purpose of quieting title to such shares, although, if he had obtained judgment for damages resulting from the fraud, he could not have satisfied such judgment by levying on the shares.

Likewise, the second reason for the Jellenik judgment does not exist under the Uniform Act. By virtue of Sections 8 and $\mathrm{I} 3$ thereof, the corporation cannot be compelled to issue a new certificate except when a certificate is lost or destroyed; and even though a court should enter a decree finding that the non-resident holder of the certificate was not entitled to any interest therein, a bona fide transferee of such holder would, by the express terms of the Act, acquire an indefeasible right to the certificate and the shares represented thereby. ${ }^{17}$

A portion of the third reason for the Jellenik decision still subsists under the Uniform Act. The domicile of the company is the state which created it, and the company has title to the property which gives the stock value. This third reason-the weakest stone in the foundation of the Jellenik case-is now treated as if it were sufficient in itself to support the decision.

The leading case holding that a suit to quiet title to stock subject to the Uniform Stock Transfer Act may be brought in the state of incorporation, notwithstanding the certificates are held outside the state, is Harvey $v$. Harvey. ${ }^{18}$ In the opinion in that case, after quoting the clause last quoted from the Jellenik opinion, the court said:

17. Decrees in equity, like judgments at law, are binding on the parties and their privies. Southern Pacific Ry. v. United States, I68 U. S. I, 48 (I897) ; Dull v. Blackman, I69 U. S. 243 (1898); Magnuson v. Clithero, I0I Wis. 55I, 77 N. W. 882 (1899); Cook, Pozvers of Courts of Equity (I915) I5 CoL. L. REv. 22S; Walsh, Development in Equity of Power to Act in Rem (Ig28) 6 N. Y. U. L. Q. REv. I, 7-I2. The legislature having provided that a decree against a non-resident holder of a certificate shall not be binding on purchasers from the certificate holder unless they have actual notice of the decree, has destroyed an important, if not absolutely essential element of an action quasi in rem. The action in rem barred all the world from claiming title adverse to that resulting from or adjudged by the decree. The action quasi in rem should, on principle, bar all parties to the action and all persons claiming through them.

I8. 290 Fed. 653 (C. C. A. 7 th, 1923). See criticism of this case in recent opinion quoted infra note 25 . 
"The language of the Supreme Court quoted above indicates the reason for holding that their situs is that of the corporation; that is, that shares of stock represent units or undivided interests in the corporate property, and must therefore have their situs with that of the corporation. They are nothing more than evidence of the holder's title to a certain number of aliquot, undivided interests in the property and franchises of the corporation." 19

The Supreme Court has pointed out the essential inaccuracy of this description of the relation of the shareholder to the corporation in severeral recent decisions. In Rhode Island Trust Co. v. Doughton, Chief Justice Taft said :

"The owner of the shares of stock in a company is not the owner of the corporation's property. He has a right to his share in the earnings of the corporation, as they may be declared in dividends, arising from the use of all its property. In the dissolution of the corporation he may take his proportionate share in what is left, after all the debts of the corporation have been paid and the assets are divided in accordance with the law of its creation. But he does not own the corporate property." 20

It is equally true that the corporation has no property interest in the shares as such. ${ }^{21}$

It is interesting to note that Judge Lindley, who rendered the opinion in the Harvey case, held in the later case of Cherry v. Insull Utility Investments that, since the decision of the Supreme Court of the United States in First National Bank v. Maine, ${ }^{22}$ the situs of capital stock is not that of the corporation issuing the same but is that of the owner. $^{23}$

The most recently reported opinion holding that the situs of shares issued under the Uniform Act is at the corporate domicile is that of a district judge in McQuillen v. National Cash Register $\mathrm{Co}^{24}$ The opin-

Ig. $I d$. at 659 (italics supplied).

20. 270 U. S. 69, 8I (1926). See also Eisner v. Macomber, 252 U. S. I89, 213, 214 (IgIg); First Nat. Bank v. Maine, 284 U. S. 312, 329, 330 (1932). The fact that property, owned by an Oregon corporation, on which plaintiff sought to establish and foreclose a lien, was located in Oregon and seized by the court, gave it no control over shares in the Oregon Company owned by non-residents so as to authorize service by publication on such shareholders. Baillie v. Columbia Gold Mining Co., 86 Ore. 1, 43, I66 Pac. 965, $97 \mathrm{r}$ (1917). Cf. Hudson Navigation Co. v. Murray, 233 Fed. 466, 469 (D. N. J. I9I6), and same case 236 Fed. 4 I9, 422 (D. N. J. I9I6).

21. National Bank of New London v. Lake Shore \& M. S. R. R., 2r Ohio St. 22r, 230 ( 1871 ).

22. 284 U. S. 312 (1932).

23. 58 F. (2d) 1022, 1024 (N. D. Ill. I932). This decision of Judge Lindley was reversed on other grounds. Guaranty Trust Co. v. Fentress, 6I F. (2d) 329 (C. C. A. 7th, I932). This case held that the situs of stock in an Illinois corporation, certificates of which were pledged in New York by an Illinois corporation, was in New York, not in Illinois.

24. I3 F. Supp. 53 (D. Md. 1935). 
ion discusses the federal cases, commencing with the Jellenik case, at considerable length, and reaches the conclusion that the Jellenik and Harvey cases must be followed until the Supreme Court itself holds that the principle of the former case is not applicable where the Uniform Stock Transfer Act is in force. ${ }^{25}$

None of the federal cases above referred to commented on several recent decisions of state courts of last resort interpreting the Uniform Stock Transfer Act and holding that the Act

“. . . prohibits a proceeding in rem against shares of stock in a corporation unless (I) the certificate evidencing the ownership of the shares be actually seized by the court or it has been brought in some way into the possession of the court; or unless (2) the certificate therefor shall have been surrendered to the corporation which issued it; or unless (3) its transfer by the holder has been enjoined. . . . In the last case, however, it is to be noted that the holder must be before the court in person, for otherwise no valid order could be entered restraining him from transferring it." 26

The recent decisions referred to in the preceding note were rendered in actions by a creditor or spouse of a non-resident stockholder to subject shares owned by such non-resident defendant to payment of a debt or judgment for alimony. The application of the express prohibition of the Uniform Act against "attachment" or "levy" is more obvious in such cases than in those in which the plaintiff claims to be the equitable owner of shares and commences suit to quiet title without

25. The only case cited in support of this decision which deserves comment is Rogers v. Guaranty Trust Co., 288 U. S. I23 (I933). The five to three opinion in that case, Stone, Brandeis and Cardozo dissenting, while citing the Jellenik case as authority for the proposition that a proceeding in New Jersey was authorized (id. at I32), failed to notice or comment on the existence or effect of the Uniform Stock Transfer Act. The briefs filed in that case did not inform the court that the Uniform Stock Transfer Act was in force in New Jersey. The majority opinion recognized that the district court in New York had jurisdiction, but held that it should have declined to exercise it because the issue involved the internal affairs of the corporation and the interpretation of New Jersey statutes.

A bill against New York stockholders in the federal district court in New York to enforce the decree of the Maryland district judge in the McQuillen case was later dismissed by the court; on appeal the circuit court of appeals said: "The plaintiffs especially rely on Harvey v. Harvey . - . but that decision, which with due respect we think highly doubtful, if it can be defended at all . . . did not involve the enforcement of a decree quasi in rem by a suit in aid of it in another jurisdiction." (Italics added.) McQuillen v. Dillon, $98 \mathrm{~F}$. (2d) 726,728 (C. C. A. 2d, I938). There is no discussion in this opinion of the effect of the Uniform Transfer Act on the situs of shares.

26. Iron City Bank v. Isaacsen, I58 Va. 609, 631, 635, I64 S. E. 520, 528 (I932). See also Amm v. Amm, II7 N. J. Eq. 185, I75 Atl. I86 (Ch. I934) ; Elgart v. Mintz, I23 N. J. Eq. 404, I97 Atl. 747 (Ch. I938), same case, I6 N. J. Misc. 289, I99 Atl. 68 (C. C. 1938), 124 N. J. Eq. 136, 200 At1. 488 (1938); Bloch-Daneman Co. v. Mandelker $\&$ Son, 205 Wis. $64 \mathrm{I}, 646,648,238$ N. W. $83 \mathrm{I}, 833$ (I93I). It is clear from the context that the language quoted above in the text was used in its comprehensive sense as including all actions in rem or quasi in rem. Attachments against property of non-resident debtors are properly classified as "proceedings quasi in rem". Freeman v. Alderson, II9 U. S. I85, I Am. Juris. 436-8. 
preliminary attachment or levy. The cases cited are, however, autthority for the statement that the Uniform Act forbids all forms of attachment, equitable as well as legal, and justify the deduction that a proceeding in equity, whereby a court takes control of shares of a nonresident represented by a lawfully issued certificate held outside the state is, in effect, an equitable attachment forbidden by the Act.

It is submitted, therefore, that decisions that one claiming to be the equitable or legal owner has the right to place the shares in the custody of a court of equity by suit to quiet title and constructive service on the non-resident holder of the certificate are not well grounded. If there has been no seizure of the res by the court, there is no jurisdiction quasi in rem. On the other hand, if the bringing of the suit in equity constitutes a seizure, then it is an equitable attachment, forbidden by the terms of the Act as construed by state courts of last resort.

The cases which have upheld the jurisdiction of courts of the state of incorporation in actions to quiet title, regardless of the location of the certificates, have failed to give due consideration to the historical development of the law as to such actions.

Originally actions to quiet title could only be maintained as to real estate against defendants upon whom personal service could be made. ${ }^{27}$ As to personal property, the only remedy analogous to an action to quiet title was the bill of the peace, which, at common law, could only be brought against resident defendants by one who was in possession of the property and who had maintained his legal title against repeated suits at law. ${ }^{28}$

Statutes in all states have greatly extended the scope of the statutory action to quiet title to real estate, and in some states the right to bring actions to quiet title to personalty has been conferred by statute. The right to bring actions to quiet title to personalty, other than bills of peace, has, however, been in large measure a judicial development of the law. Some courts have denied such right; but the majority have recognized it, often without any discussion of the necessity for control of the res through attachment, receivership, sequestration or possession by plaintiff. ${ }^{20}$

The leading authorities on the subject of actions quasi in rem recognize that control over the res and power to make its judgment effec-

27. Arndt v. Griggs, I34 U. S. 3I6 (I890); Wehrman v. Conklin, I55 U. S. 3I4, 33I, 332 (I894); PoMEROY, EQUITY (4th ed. I9I9) \$ 1436.

28. Lowe v. Lowry, 4 Ohio 77 (1829).

29. Notes (I933) 87 A. L. R. 485, (1936) 105 A. L. R. 291. Since the cases in which judgments quasi in rem have been rendered as to personal property without seizure other than making the local custodian a party to the action, give no reasons for considering summons as the equivalent of a writ of injunction, attachment or sequestration, they are not of great weight as precedents. Certainly few lawyers would bring an action to quiet the equitable title to a chattel in the custody of a resident agent of $a$ non-resident claimant without either a receivership of the property or an injunction against the resident agent. 
tive are essential conditions to the exercise of such jurisdiction. ${ }^{30}$ Real property, being permanently located in a state and not merged in any document, is deemed to be within the control of courts of general jurisdiction in the district where the real estate is located; and, therefore, no seizure other than the mere commencement of the suit is necessary as a prerequisite to service by publication on non-residents in actions quasi in rem. ${ }^{31}$

Personal property, on the other hand, if not in the actual possession of plaintiff, cannot, on principle, be made the subject of an action quasi in rem so as to justify service by publication unless it is effectually brought within the control of the court prior to the commencernent of service by publication. ${ }^{32}$ Such control may be gained by injunction against a resident custodian, or by attachment of the property; or it may exist because the property is in the actual possession of plaintiff. ${ }^{33}$ If control is not obtained in some such manner, then the mere location of personal property within the state is not a sufficient basis for an action in rem or quasi in rem since the court has no effective control over the property. ${ }^{34}$

30. Waples, Proceenings in ReMr (I882) $\$ 42$ : "What citation is, in a personal civil action, seizure is in the actio in rem, so far as it is notice to all interested. It is absolutely essential to the existence of the action, to the jurisdiction of the court, to the validity of the condemnation." Id. $\$ 43$ : "I Let it be never questioned that proceedings in rem are void $a b$ initio without seizure sufficient; that there is no reliable decision, and can be none, to the effect that insufficient seizure can be cured by anything less than the making of it sufficient." Pennoyer v. Neff, 95 U. S. 7I4, 727-8 (I877); Tyler v. Defrees, II Wall. 33I, 348-9 (U. S. I87o) ; McDonald v. Mabee, 243 U. S. 9o (19I7); United States v. Bank of New York, 296 U. S. 463, 477 (1936); Amparo Mining Co. v. Fidelity Trust Co., 75 N. J. Eq. 555, 558, 73 Atl. 249, 250 (I909) ; Hanna v. Stedman, 230 N. Y. 326, I30 N. E. 566 (I92I).

3I. Reed v. Reed, I2I Ohio St. I88, I67 N. E. 684 (1929). See cases collected in Note (I937) 108 A. L. R. I302.

32. In divorce and alimony proceedings under special statutes it has been held that it is sufficient if the property be seized before inquiry as to award of alimony and as to application of property to payment. Geary v. Geary, 272 N. Y. 390, 6 N. E. (2d) 67 (1936.) This is explained on the theory that the marital status involved in itself justified service by publication. But if actual seizure does not precede entry of judgment, the judgment is void. Matthews v. Matthews, 247 N. Y. 32, I59 N. E. 713 (1928). In Boudwin v. Boudwin, 20 F. Supp. 903 (E. D. Pa. I937), service of notice of a decree on the husband was held sufficient to sustain judgment in rem, apparently without any prior service or seizure. The Pennsylvania authorities cited do not go so far. Boudwin v. Boudwin, 320 Pa. 147, I82 Atl. 536 (1936) ; Erdner v. Erdner, 234 Pa. 500, 83 At1. 420 (I9I2). In Ohio in alimony cases relating to shares of stock, a preliminary injunction was served on the corporation. Cleveland \& Buffalo Transit Co. v. Beeman, I2 Ohio Cir. Ct. (N. s.) 460 (Ig09), aff'd, 8I Ohio St. 509, 91 N. E. Ir26 (Ig0g).

33. Control by injunction or receiver: Pennington v. Fourth Nat. Bank, 92 Ohio St. 5 I7, II2 N. E. ro85 (Igr5), aff'd, 243 U. S. 269 (IgI6); Loaiza v. Superior Court, 85 Cal. II, 24 Pac. 707 ( I89o) ; Benner v. Benner, 63 Ohio St. 220, 58 N. E. 569 (I900); Cleveland \& Buffalo Transit Co. v. Beeman, I2 Ohio Cir. Ct. (N. s.) 460 (Ig09), aff'd, 8I Ohio St. 509, 9I N. E. II26 (I909). Seizure by attachment: Ball v. Towle Mfg. Co., 67 Ohio St. 306, 65 N. E. I015 (I902). Possession by plaintiff : First Trust Co. v. Matheson, I87 Minn. 468, 246 N. W. I (r932), 87 A. L. R. 485 (I933); Magnuson v. Clithero, Ior Wis. 55I, 77 N. W. 882 (I899); Closson v. Closson, 30 Wyo. I, 2I 5 Pac. 485 (I923), 29 A. L. R. I38 (1924).

34. The fact that the adequate remedy must be sought outside the state is not in itself sufficient to justify a resort to equity. Alkin v. Chartered Co., III Me. 556, 90 
Statutes, in sections of the code dealing with procedure as to service of process, and specifying the various actions in which service by publication may be made on non-residents, are intended merely to provide for the method of service in actions which could be brought under prevailing principles of the common law or equity, or under statutes creating substantive rights-not as creating causes of action against non-residents of a sort which could not be maintained against residents. $^{35}$ If, therefore, a plaintiff does not subject personal property to such actual control of the court as would entitle him to bring suit to quiet title against a resident, he is not entitled to bring such suit against a non-resident merely because the statute specifies an action relating to personal property in the state "where the relief demanded consists in excluding the defendant from some interest therein" as one of the actions in which service by publication may be made.

Decisions holding that courts of the state of incorporation have jurisdiction quasi in rem over shares subject to the Uniform Stock Transfer Act, represented by certificates held outside the state, have also disregarded the principle that equity will not take jurisdiction when there is an adequate remedy at law, or when the only adequate remedy in equity can be obtained in another jurisdiction. ${ }^{36}$

Courts which have upheld the right to bring actions to quiet title to other classes of personal property have usually limited such right to cases where there is no adequate remedy at law..$^{37}$ Decisions upholding jurisdiction quasi in rem over corporate stock not subject to the Uniform Stock Transfer Act in cases where the corporation has been made a party to the action, but has not been enjoined from transferring the shares which are the subject of the action, apparently proceed on the theory that such shares have as firm an anchorage in the state of incor-

At1. 427 (I9I4). Since three state courts of last resort have agreed that under the Uniform Act the corporation cannot be enjoined from transferring shares represented by a lawfully issued certificate held outside the state unless the holder of the certificate is before the court in person (see supra note 17 ), it seems practically certain that this construction will be adopted in other states pursuant to that section of the law which requires construction "to make uniform the law of those States which enacted it". The writ of attachment or injunction is the preliminary process used at law or in equity whenever effective seizure of a chattel within the jurisdiction is required. To hold that mere service of summons, or such other process as is required to make a corporation a party to an action, operates as effective seizure of its shares, in states and under circumstances where the court is prohibited from seizing shares by attachment or injunction, is to ignore the clear intent of the law. Such a decision can only result from following earlier holdings as to situs, made at a time when the law permitted seizure of shares by attachment or injunction served on the corporation.

35. Roller v. Holly, I76 U. S. 398 (Ig00).

36. Ellis v. Dixie Special Highway \& Bridge Dist., I03 Fla. 795, I38 So. 374 (193I); Note (1936) I05 A. L. R. 291.

37. Thus, in Voss v. Murray, 50 Ohio St. I9, 32 N. E. III2 (I893), the property was in the possession of the sheriff under attachment, and the attaching creditor had, therefore, no possessory action against the other claimants. 
poration as real estate itself, and that making the corporation a party gives the court the same control over the interest of the non-resident shareholder as the presence of real estate in the state gives over the interest of a non-resident claimant. ${ }^{38}$ Such decisions ignore patent distinctions between control over real estate and control over shares, which should have affected the exercise of the chancellor's discretion. The non-resident claimant to real estate does not hold a quasi negotiable evidence of title, issued by a disinterested artificial person, entitling the party to whom it is issued to have it transferred on the books of the issuer - a document which may be transferred to a bona fide purchaser during the pendency of an action quasi in rem, passes from hand to hand, and may even be surrendered and transferred on the books of the issuing corporation prior to judgment in the action against the nonresident holder. There is, therefore, no occasion for an injunction against the transfer of evidence of title to real estate.

Prospective purchasers of real estate not only have the means of ascertaining whether there are pending suits affecting the title by examination of the public records in the county or judicial district where the real estate is situated, but such search is customary and is required by ordinary prudence. On the other hand, a prospective purchaser of stock would have no right to examine corporate records and would have no practical means of ascertaining whether suits affecting the title of the seller had been commenced since such suit might be commenced in any county or judicial district in the state of incorporation where service could be made on proper officials of the company. When, therefore, a plaintiff asks a court of equity to quiet title to stock, the certificates for which are held by a non-resident, he should be required, as a preliminary to service by publication, to give the court such control over the res as is practicable; $i$. e., he should obtain a preliminary injunction against transfer of the shares by the corporation. ${ }^{39}$ The fact that possible

38. See discussion supra p. 702.

39. See supra notes 20-24. Questions as to rights of transferees pending suit or subsequent to judgment will be practically eliminated as to shares subject to the Uniform Act if the theory of this article is adopted and the holder of the certificate enjoined from transfer pending suit.

In Holmes v. Camp, 219 N. Y. 359, 37I, II4 N. E. 84I, 844 (IgI6), dealing with shares not subject to the Uniform Act, the possibility that its judgment as to shares represented by certificates held outside the state might be rendered futile through transfer of certificates, was said to be a question "not now before us and not to be considered".

In Amparo Mining Co. v. Fidelity Trust Co., 75 N. J. Eq. 555, 560, 73 At1. 249, 25I (Ig09), the court said: "We are not now concerned with the possible rights of a bona fide transferee of the present certificates." If the courts had reference to the transferee's personal right of action for damages, their statement is justified. If they had reference to possible rights in the res which could be acquired in spite of the court's decree, then the possibility of such rights was a matter with which the court should have been concerned in determining their jurisdiction. Since the corporation was the plaintiff in the Amparo case and since the Holmes v. Camp suit was on behalf of the 
liability to damages in a separate action would probably deter a corporation from making a transfer during the pendency of an action to which it was a party, is not a satisfactory or legal substitute for the direct control, through summary process, which would be afforded by injunction.

There are two situations in which it is generally recognized that mere service of summons on one having actual possession and effective control of personal property gives the court effective control over the res. One is the common case of a creditor's bill to reach equitable assets. In such case, in the absence of special statutes, the creditor must first have obtained judgment at law, and the commencement of the suit is "an equitable attachment". ${ }^{40}$ The other is an escheat proceeding, governed by special statutes, the commonest case being that of a suit by the state against a bank to recover unclaimed deposits, with personal service on the bank and service by publication on depositors whose addresses are unknown. ${ }^{41}$

These cases afford no justification in principle for holding that control over shares subject to the Uniform Stock Transfer Act, sufficient to justify service by publication, is obtained by making the corporation a party.

There is probably no branch of the law in which the doctrine of stare decisis should be applied more cautiously than in that governing the situs of intangibles-particularly of such artificial intangibles as corporate shares, whose determinative characteristics are subject to frequent change by statute. The courts recognize that when they ascribe a situs to intangible property they are applying a legal fiction. ${ }^{42}$

The determination as to what legal fiction should be applied and as to what effect should be given to a situs determined merely by the application of a legal fiction has varied not only in different jurisdic-

corporation, the property from which the cloud was to be removed was subjected to the jurisdiction of the court by the plaintiff; and seizure by injunction against the plaintiff by or on whose behalf the action was brought, was unnecessary.

It appears from the statement of facts in Jellenik $v$. Huron Copper Mining Co. that the bill prayed for an injunction against transfer of the illegally issued stock pending final order of the court. It does not appear in the report of the case, however, that any preliminary injunction was issued. The opinion of the court contains no intimation that the issuance of such an injunction was a prerequisite to jurisdiction over nonresident shareholders. However, the plaintiffs in that case were in possession of their stock and therefore the property, title to which was quieted against the claims of nonresidents, was subjected to the control of the court by the plaintiffs. That case is not authority for dispensing with an injunction when the facts alleged do not show that the shares held by the non-resident were illegally or fraudulently issued.

40. Rioux v. Cronin, 222 Mass. 13I, I09 N. E. 898 (I9I5).

4I. Security Savings Bank v. California, 263 U. S. 282 (1923). In cases involving confiscation of enemy property seizure usually precedes court action. Miller v. United States, II Wall. 268 (U. S. I870) ; Tyler v. Defrees, II Wall. 33I (U. S. I870).

42. Safe Deposit \& Trust Co. v. Virginia, 280 U. S. 83 (I929); Farmers Loan \& Trust Co. v. Minnesota, 28o U. S. 204 (I930); First Bank Stock Co. v. Minnesota, 30r
U. S. 234 (1937). 
tions, but in the same jurisdiction. ${ }^{43}$ When, therefore, material attributes of an intangible created by statute have been changed by statute, the question of the situs of such intangible under existing law should be determined on principle by a consideration of its existing characteristics rather than by precedents decided under prior statutes.

The above argument has established to the satisfaction of the author that the sole situs of shares represented by lawfully issued certificates subject to the Uniform Stock Transfer Act is that of the physical location of the certificate. The question whether suits may be brought in the state of incorporation to cancel shares, the issuance of which and of the certificates therefor were ultra vires, or in fraud of the rights of other stockholders, is much more debatable. The question is raised, but not decided in the exhaustive opinion in the recent case of Elgart v. Mintz.44

It may and probably will be held that the subject matter of the Uniform Stock Transfer Act is lawfully issued shares; that it could not have been the intention of that Act to take away from the state of incorporation jurisdiction to determine, at the suit of the corporation or of the stockholder, whether outstanding shares were in fact lawfully issued. The jurisdiction is clearer in the case of an ultra vires issue than in the case of an issue made in accordance with legal formalities, but in violation of fiduciary duty. In the latter case it may be argued that the courts of other jurisdictions are as well qualified as those of the state of incorporation to determine questions of actual fraud; and that certificates issued in accordance with legal formalities by officers of the corporation are, in so far as bona fide purchasers are concerned, lawfully issued certificates and should be treated in all respects as subject to the Uniform Stock Transfer Act.

It is interesting to note that several of the cases which have announced as a general principle that the state of incorporation is the situs of shares subject to the Uniform Stock Transfer Act, could have been decided on the special fact that the shares of the non-resident defendants in that case were not lawfully issued shares; ${ }^{45}$ or on the point that the question involved was the right of individual defendants to vote stock within the state under contracts binding on them, but not necessarily binding on successors in title to the shares. ${ }^{46}$

43. Blackstone v. Miller, I88 U. S. I89 (I903) ; Farmers Loan \& Trust Co. v. Minnesota, 280 U. S. 204 (I930) ; First Nat. Bank v. Maine, 284 U. S. 3I2 (I932).

44. I23 N. J. Eq. 404, 414, I97 Atl. 747, 753 (1938).

45. McQuillen v. National Cash Register Co., I3 F. Supp. 53 (D. C. Md. I935).

46. Shinkle v. Dayton Adding Machine Co., I9 Ohio N. P. (N. s.) I04 (C. P. Ig16). As to some issues, see Harvey v. Harvey, 290 Fed. 653 (C. C. A. 7 th, 1923). The court could punish by summary process violation of its orders as to voting stock at a meeting held in the state. 